Journal of Business Management and
Economic Research
2020, 4 (3) DOI: $10.29226 / \mathrm{TR} 1001.2020 .206$
Journal Homepage: $\underline{\text { https://www.jobmer.org }}$

\title{
Effect of Employee Political Skills on Employee Performance in Kenyan Universities
}

\author{
Lelei Joy Chelagat \\ (PhD Student) \\ Department of Management Science, Moi University, Kenya \\ chelajoy82@gmail.com
}

\begin{abstract}
The objective of this study was to determine effect of employee political skill on employee performance in Kenyan universities. The study was grounded by social exchange theory in positivism study and adopted explanatory research design. Data was collected using questionnaire from a sample size of 567 academic and non-academic staff that were randomly selected from target population of 6147 employees in Kenya. The reliability of the data collection instrument was presented using Cronbach Alpha while factor analysis was used to validate the instrument. The study findings revealed that Employee Political skill had a positive and significant effect on employee performance $(\beta=.467, \mathrm{p}<.05)$. This finding implies that universities that equip employees with political skills are likely to experience high job performance. The study recommends leaders in institutions to instil the resource of employee political skill so as to enrich performance among employees.
\end{abstract}

Keywords; Political Skills, Employee Performance, Universities

\section{Suggested Citation:}

Chelagat, L. J. (2020). Effect of Employee Political Skills on Employee Performance in Kenyan Universities. Journal of Business Management and Economic Research (JOBMER), Vol: 4, Issue: 3, 281- 298.

\section{Introduction}

Employee's performance can be considered as backbone of organization as it leads to its development effectively. Currently organizations are compelled to contend and behave in a competent way in such a tough era; as such, it is very crucial to have a qualified team that are reliable in generating competitive edge(Sofijanova \& Chatleska, 2013).To remain in competitive market environment there 
is high need for firms to consider enhancing employee's performance which is also an important tool for firm performance(Herman, 2014).Above all, firms are discovering that people really are the most important assets hence the need to make them participate in issues related to their welfare (David, 2015). Kuvaas (2018) asserts that native organizations maintain unparalleled traditional methods by managing employees as a clerical function generating significant distinctions on HRM practices such as political skills causing variance in employees' performance.

Employee Political skill is considered to be a complete design with reasonable perception, operative and good work ethics that reflect upon ones conduct when it comes to interconnection. People with political skills take note of how others are behaving and get to know how to correctly communicate, conduct themselves and others. They are also aware of their personality and are strongly accustomed to different public settings. According to Sharma and Hussain (2013), workers that practice political behaviour go through a lot of feelings to meet requirements of a job though this connection works in various ways when it comes to political skills. Staff with little political skills experience emotional labour as an aftermath though moving responses from political conduct were nullified for people with high political skills. A staff dedication is caused by expressive affection for the company. As proven by Ferris et al., (2017) and Semadar et al., (2016), political skill shows someone's capability to become a better person through changing their actions, understand other peoples conduct and have an impact on their action in a safe and honest way.

Employees' performance level in 2015 in sub- Saharan Africa economies was the lowest among all regions. Organizational specialists see this fact as a persistent problem for the organization (Yin-Fah et al., 2010). This is believed to be a stern problem due to its harmful effects on the organization mainly when the high performing employees quit from the organization. Precisely, Universities in Kenya are faced with uncertain deviations in employee political skill, commitment and organizational citizenship behaviour. There are no empirical studies in Kenya that show the effect of employee political skill on employee performance in universities and other sectors which this study strived to achieve.

\section{Literature Review}

As attested by Ferris, Treadway et al., (2005) employee political skills have been described as the capacity to successfully comprehend the rest at the work place, as well as putting this know how to use in impacting the rest to behave in ways that improve individual as well as firm rationales. Therefore, politically apt persons put together social intelligence and their ability to cope with dynamic situational requirements in a way that seems to be genuine, stimulates trust and support and sufficiently impacts and regulates the reaction of others. Political skills, therefore is based on proficiencies that are revealed 
in job related scenarios, which shines light on situation volatility as well as attitudinal determinants. On the other hand, the variance due to attitudes is stronger; the variance due to situations can be influenced.

Political skills can assist in counteracting responses to job stressors. Perrewé et al., (2004) and Perrewé et al., (2005) contend so whereas Ferris, Treadway et al., (2007) asserts that persons with elevated political skills portray a subtle self-belief due to feelings of control in addition to their personal sense of safety which allows them to keep up balance and outlook. Ferris et al., (2005) later suggests that individuals with superior political proficiency are less likely to find surrounding pressures as terrifying.

Individuals with weak political skills are more inclined to capitalise on institutional response practices for instance coming back or engaging in defamatory behaviour given their inferior understanding in making use of alternative influence techniques for instance being civil. Harrell-Cook Ferris and Dulebohn (1999) earlier discovered that those well versed with political skills employ tactics such as flattery to attain their objectives, which in this instance would be to ensure just treatment. Indeed Treadway, Ferris, Duke, Adams and Thatcher (2007) realised that managers who perceived staff with superior political skills employing persuasive techniques and found it to be a sincere attempt while those who have low political skills using persuasive techniques as an outright attempt to coerce for selfserving intentions and thus have fewer odds at attaining their objectives.

Employee politics was incorporated into management publications thirty years ago. Ferris \& Treadway, 2012; Vigoda-Gadot \& Drory, (2006) contends that the importance of institutional politics for the public and private industries has been affirmed by a vast amount on studies carried out worldwide regarding its linkages and results. In the past few years, studies on institutional politics at the job has been centred on the paradigms of political skills (Blickle, et al., 2012; Silvester, 2008 ;). Ferris, Treadway, (2012), in a short description cite that political skills can be viewed as a complex sequence of social astuteness, with psychological, affective and practise revelations.

Blickle, Oerder et al., (2010) conducted an analysis of the political skills of German work ambassadors as well as its probability of their culmination in career. This analysis estimated these works ambassadors political skills and established that is essentially played a role in the eminence of their careers (for instance. a case of analysing career based on triumph in elections), when age, sex and fraternity affiliation are regulated. The concept of career eminence has in several instances been widely studied for an extended period of time and discovered to be influenced by conventional elements such as, job linked skills and individual performance record, in addition to political techniques, proficiencies in social skills and networking capacities. ( $\mathrm{Ng}$ et al.,2005). 
It seemed fitting then, to analyse the part played by political skills in career eminence and commitment. When viewed from the outlook of institutional politics, careers can be referred to as political campaigns, (Inkson, 2004), entailing searching for contacts, expanding networks,( Treadway, Breland, Adams, Duke, \& Williams, 2010), impression management (Bolino \& Turnley, 2003), self-promotion (Higgins, Judge, \& Ferris, 2003) and use of influence techniques. As such career eminence is essentially dependent on personal skills like political skills (Blickle, Oerder, \& Summers, 2010), that allow for the successful sustenance of good impressions across different work set ups, more so for pictures that contribute to the examination of performance and career prospects. In addition, given that politically apt persons are more likely to effectively attain the career objectives they wish, they are more probable to achieve satiety with their careers.

Vigoda-Gadot, Vinarski-Peretz, and Ben-Zion (2003) proclaimed "outlook on politics more often than not views about the degree of sovereignty and authority employed by other institutional members to achieve benefits and protect their interests in situations of conflict." Valle and Witt (2001) stated “Organizational politics can assume both positive and negative meaning. "Institutional performance is negatively impacted by the outlook of politics (Byrne, 2005).According to Harrell-Cook and Dulebohn (2000) statement concerning perception of institutional politics "it entails a personal assignation to habits of self-serving causes and is defined as an individual's bias assessment of the degree to which the job surrounding is represented by fellow staff and managers who portray such self-benefiting habits.

\section{Hypothesis Development}

Proactive personality has been related to extrinsic job-related outcomes such as employee performance which leads to extrinsic career success, or actual advancements in salary and position (Seibert, Kraimer, \& Crant, 2001). In an effort to assess the category validity of the Proactive Personality Scale, they discovered that proactive personality accounted for $8 \%$ of the variance in unbiased estimates of employee performance as in the case of real estate dealers. Furthermore, proactive personality has been linked with other non-bias estimates for instance remuneration and promotion (Seibert, Crant, \& Kraimer, 1999). Proactive personality was also discovered to be fundamentally linked to bias performance reviews by direct managers in different surroundings (Thompson, 2015) as they tend to set high standards, and harness all available resources into achieving those standards.

Bowling, Beehr, (2005) argued that proactive persons actively initiate development within their surroundings, while less proactive individuals take up a more reactive outlook towards their work. As such, proactive personality make intentional trials to stir up development in their surroundings, and 
is essential in today's institutions depicted by fast changes and reduced supervision due to the great levels of performance created. Proactive personality leads people to a specific degree of effectiveness (Wagner, \& Libkuman, 2005). As a matter of fact, two significant analyses discovered that proactive personalities, which happen to influence job satiety, may be responsible for upto $30 \%$ of the varience in employee performance. Proactive personality may have a precise effect on employee commitment and may impact the way in which employees view their work which in turn influences the results of the firm (Bowling et al., 2005). Proactive personality will most likely influence job commitment as proactive individuals will be more satisfied with their jobs because they will remove obstacles preventing satisfaction hence performance (Erdogan \& Bauer, 2005).thus, the study hypothesized that;

\section{H1: proactive personality positively affect employee performance}

Under high perceptions of a victimizing environment, the politically skilled will succeed in utilizing their social astuteness by adjusting their interpersonal influence practise for a short time to facilitate performance related resource transactions without exposing themselves to risk and in the long haul as well to collect reinforcements to dissolve existing and rising risks. In line with (Treadway et al., 2013) task performance can assist people to attain the rewards and results needed to promote their social resources, and is positively associated with increased political skills (Ferris et al., 2005; Jawahar et al., 2018).

Judging from current scientific and theoretical work, McAllister et al., (2016) contended that political skills improve the social influence procedure in three levels: recognition of opportunity, prospect evaluation and prospect capitalization. The social astuteness and interactive capacity of politically skilled workers helps them become more socially embedded, which in- turn leads to more opportunities to influence co-workers towards performance and other organizational benefits.

The main purpose of organizational social astuteness is to instigate the employee an active member of the organization. While a successful socialization of an individual increases organizational commitment, solidarity and success rate (Balci 2000), admission of a person to the institution to begin a career and their career growth is contingent on the fraternizing program enacted by companies as well as the individual's performance in the program. Socialization does not only encourage staff to gain organisational commitment, it also smoothens their integration into the institutional guiding principles, codes, techniques, norms and social linkages. In cases where an employee is not able to get socialized into the system, they may be forced to leave the institution and this scenario negatively affects both the employee and the organization in terms of loss of job and performance respectively. Hence our second hypothesis stated below. 


\section{H2: Social Astuteness positively affect employee performance}

Individuals with greater political skills are well versed with creating and taking advantage of different networks of people. Individuals in such networks tend to hold resources viewed as priceless and requisite for efficient operation of the institution as well as the individual. Due to their general refined fashion, politically skilled people find it easy to build associations and foster robust confederations and coalitions. Moreover, since social networks are intentionally built systems, people with superior connecting capacities see to it that they are well placed to both generate and take advantage of opportunities, Baron \& Markman, (2000). Masters of the quid pro quo, they are often highly skilled negotiators and deal makers, and adept at conflict management.

A study on networking ability of German work ambassadors and its probability of their career thrive was assessed by Oerder et al., (2010). This analysis assessed these works ambassador's political skills and established that it played a fundamental role in their career development when age, union affiliation and sex are held at constant. The concept of career thrive has continuously been investigated for a prolonged period and discovered to be influenced by conventional attributes, for example work linked skills and one's performance record, and also by networking abilities, political tactics, and social skills competencies ( $\mathrm{Ng}$ et al., 2005).

The role of networking ability in the supervisor-employee association dynamics playing a part in career opportunities, using several sources of information in Chinese companies as analysed by Wei et al., (2010). An aggregate of 343 workers, their 343 direct superintendents and 662 contemporaries filled in surveys to investigate a framework that implying that low level employees make use of their networking ability in a bid to impact their association with their immediate bosses which eventually plays a card in unlocking better career opportunities and development. Also, a meta-analysis (Eby, Sorensen, \& Feldman, 2005) concludes that political expertise and social capital for example, quantity or quality of accumulated contacts can act as dominant predictors of career success.

Networking ability gradually turned into the third fundamental determinant of employee's success in their job. On the basis of publications, the politically skilled are well averse in exploiting their circles by making sure that they are linked to impact others and that they are well placed to gain and create prospects. Furthermore, Blickle et al., (2009), in their extensive researched ascertained that networking ability speculated fulfilment in one's career, stratified status and earnings. Only when employees are strong with networking ability, are they able to navigate the political environment at workplace thereby optimizing resources and power, can exercise influence, and are able to gain personal and organizational goals. 


\section{H3: Networking Ability positively affect employee performance}

Self-monitoring is also another psychological variable described as critical and computable personal variances and behavioural attributes (Becker, 2004). Various researches have analysed the influence of self-monitoring at work and have deduced that persons with optimum self-monitoring have superior social skill. Furthermore, most scholars discovered that males are more self-monitored as compared to females. Pasha, (2009) cites that high or low self-monitoring in people is contingent on practices, beliefs and disposition. While Rachlin (1999) is of the opinion that individual with high self-monitoring has higher employee performance within the organization in which they work for.

In his study, Zaki (2003) claims the existence of a linkage between organizational commitment and selfmonitoring. In his analysis, Dobrin also touches on the linkage between individual attributes and employee commitment; he discovered that individual attributes enhance the likelihood of an individual to seek an attachment. In their analysis, Sharifi and Salami (2010) established that frameworks of neuroticism, introspectiveness, compatibility and dutifulness could predict employee performance. One of the cognitive characteristics that has cognitive source is locus of control that affects many of job aspects of managers and employees.

Concerning a study suggesting self-monitoring and locus of control affect organizational performance, findings expressed that variables of self-monitoring and essence of control do not bear impacts by themselves, but when integrated. In line with the first part of the hypothesis brought forward implying the influence self-monitoring has on organizational commitment, the findings of the current study were inconclusive. It is Rachlin's (1999) perception that persons with superior self-monitoring tendencies have elevated commitment. In elucidating the findings of this study, Boswell (2001) attests that high or low self-monitoring in individuals depends on the difference in attitudes, behaviours and beliefs.

On the other hand, self-monitoring is a distinct individual attribute unique to each person, in simpler terms, persons with high self-monitoring exude unique responses and tendencies depending on the degree of self- monitoring. High or low self-monitoring demonstrates cultural superiority, social norms, values, individual attributes and moral fabric of individuals. Other results also indicate that religion and its teachings are effective in creating self-monitoring in individuals.

In line with the above findings concerning the impacts of some criteria for instances culture, values, attitudes, religion individual diversity and gender on persons with low or high self-monitoring and given that the education system is among the institutions where a cluster of individuals are imparted with several perceptions, values and diversity among individuals that are not computed in the analysis, certify our failure to attain conclusive results in the investigation. 


\section{$H_{4:}$ Self-monitoring positively affect employee performance}

According to DePasquale and Geller (1999), high level of interpersonal influence is advantageous for institutional operation. In his study, McAllister (1995) broke down interpersonal trust into two forms, affect-based and cognitive interpersonal trust. Trust that is cognitive in a firm environment entails. Reliability, dependability, proficiency, and responsibility, on the contrary, affect-based trust involves fervent attachments between teammates (McAllister, 1995). McAllister, (1995) conducted an interview involving 194 supervisors and experts, his findings showed that supervisors with optimum affectbased trust in their co-workers tend to pursue opportunities to fulfil the needs of colleagues that are work-affiliated in addition to participating in constructive intervention. This study builds path for future research on how trust among managers in organizations influence their behaviour and performance.

Trust is affective; in line with fervent attachments between persons. People invest in such sort of trust relationship by showing sincere concern for the wellbeing of other members, stand by the natural virtue of such associations and that such feelings are returned. Affective trust is proximally linked to the idea that a fellow's actions are congenitally inspired and represented by feelings of safety and recognized tenacity of the relationship. So the emotional ties that link individuals are accepted to be the basic antecedent for trust.

According to the study of Baker, (2007) in a commitment system, employees and the institution are seen as holding each other in high respect and incentives encourage social practices such knowledge exchanges, peer guidance and reinforcement. His research brought forward that social support attained from peers has an explicit definitive linkage to commitment which impacts employee performance as a whole. In line with the findings of this research, Chen, (2002) stated that peer support has an additive effect performance in the organization.

H5: interpersonal influence positively affects employee performance

\section{Material and Methods}

The study adopted positivism approach. In this study positivism was an applicable perspective because effect of employee political skills on performance of staff was assessed without bias through the use of existing theoretical models as well as structured tools to measure and investigate it, after which conception was done from the discoveries. Explanatory research design is centred on situational analysis or a particular issue to elaborate the sequence of linkages between variables. The study targeted 6147 academic and non-academic staff from two top public universities (University of Nairobi and Kenyatta University) and two Private (Strathmore university and United States International 
University), (University HR records, 2018;www.4icu.org/ke). Systematic sampling was used to select employees in each university to constitute the sample. Primary data was obtained from the universities employees using questionnaires.

\subsection{Measurement and Operationalization of Variables}

\subsubsection{Dependent variable}

The questionnaire was applied to know the performance of employees in universities. It was developed and validated by Pradhan et al., (2017). Responses were recorded on 5-likert scale, 1=strongly disagree and $5=$ strongly agree. It had 23 items in all types of employee performance they included (Task performance-6 items), (Adaptive performance-7 items) and (Contextual performance-10 items) the high score showed high employee performance and low score showed low employee performance.

\subsubsection{Independent Variables}

The study adopted items for the political scale dimensions from Political Skill Inventory (PSI) Ferris, Treadway et al., (2005) which were; proactive personality (nine items), social astuteness (eight items), interpersonal influence (eight items), networking ability (eight items), and self- monitoring (eight items). The PSI consisted of forty one items which participants answered by indicating to what extent they agreed or disagreed with each statement about themselves in the workplace on a one (strongly disagree) to five (strongly agree) Likert scale. A sample item was, "I am good at getting people to like me." Each PSI item related to one of the five dimensions of political skills (i.e. proactive personality, social astuteness, interpersonal influence, networking ability, and self-monitoring). The mean score of all items within a dimension indicates the participant's proficiency in that specific dimension of political skills. The mean score of all forty one PSI items indicated the participant's total political skills proficiency. Individual political skills within a dimension and overall were defined by Ferris, Davidson, and Perrewe (2005).

\subsection{Model specification}

Collected data was analysed using multiple regressions and correlation analysis, the importance of every independent variable was measured at an accurate level of $95 \%$. The research's regression equation was applied as depicted below; the coefficients beta $(\beta)$ for each independent variable was formulated from the model, subjected to a $t$-test, in order to test each of the hypotheses under study. The regression model that was used to test is shown below;

$y=\alpha+\beta_{1} x_{1}+\beta_{2} x_{2}+\beta_{3} x_{3}+\beta_{4} x_{4}+\beta_{5} x_{5}+\varepsilon$

Where, $\mathrm{Y}=$ Employee performance

$\alpha=$ Constant 
$\beta_{1} \ldots \beta_{5}=$ the slope representing degree of change in independent variable by one unit variable.

$\mathrm{X}_{1}=$ Proactive personality

$\mathrm{X}_{2}=$ Social astuteness

$\mathrm{X}_{3}=$ Networking ability

$\mathrm{X}_{4}=$ Self- monitoring

$\mathrm{X}_{5}=$ Interpersonal influence

$\varepsilon=$ error term

\section{Findings}

This section discusses the research findings for quantitative. SPSS version 24 was employed to highlight any errors of perceived variables in the information file. Kurtosis and Skewness on every one variable were investigated for univariate anomalies. In the event (s) that anomalies were identified from the sample, distant and influence studies were carried out to determine individual case(s) as outliers at the multivariate level.

\subsection{Sample characteristics}

Most of the employees are between 36-45 years in Kenyan Universities being the youth. employees possess the requisite experience to perform their duties effectively. As such, the employees' job experience is part of the organisations' human capital. There was an almost equal representation of both male and female employees though male employees comprise the majority. Since both male and female individuals are given a chance to share their knowledge, the outcome for the organisation is likely to be greater.

Table 1. Demographic Characteristics

\begin{tabular}{llcc}
\hline & & Frequency & Percent \\
\hline age bracket & 35 years and below & 106 & 24.8 \\
& 36-45 years & 157 & 36.8 \\
& $46-55$ years & 151 & 35.4 \\
job tenure & Over 55 years & 13 & 3 \\
& 1-10 years & 29 & 6.8 \\
& 11-20 years & 120 & 28.1 \\
& 21-30 years & 196 & 45.9 \\
highest Educational Level & Over 31 years & 82 & 19.2 \\
& Undergraduate & 94 & 22 \\
& Post graduate & 145 & 34 \\
Gender & Doctorate & 188 & 44 \\
& Male & 216 & 5.6 \\
\hline
\end{tabular}




\subsection{Univariate analysis}

Finding's in table 2 below show that universities employees are willing to perform their duties regardless of the situation $(M=4.26)$. Proactive personality $(M=4.44)$ shows that universities employees are willing to actively commit their personality to the university. social astuteness $(M=3.77)$ shows that university employees offer most of their social astuteness to the achievement of the university's objectives. Finally, the results indicate that most of the respondents employees introduce people to each other who might have a common strategic work interest $(M=3.71, S D=.75)$. Self-monitoring $(M=3.94)$ shows that universities employees use most of their self-monitoring traits to the achievement of the university's objectives. The Pearson's correlation coefficient assesses the degree to which quantitative constructs are linearly related in a sample (Nikolić et al., 2012). From the results in table 2, there is a positive and significant correlation between the independent variables and employee performance. Proactive personality positively correlate with employee performance $(r=.807,0<.01)$. Moreover, results indicate that social astuteness positively relates to employee performance $(r=.497,0<.01)$. From the results, networking ability was positively and significantly correlated to employee performance ( $\mathrm{r}$ $=.459, \mathrm{Q}<.01)$. The correlation results showed that self-monitoring has a positive and significant relationship with employee performance $(r=.500, \varrho<.01)$. Interpersonal influence positively correlate with employee performance $(r=.571, \mathrm{Q}<.01)$.

Table 2. Univariate Analysis

\begin{tabular}{|c|c|c|c|c|c|c|c|c|c|}
\hline & & Mean & $\begin{array}{l}\text { Std. } \\
\text { Dev }\end{array}$ & 1 & 2 & 3 & 4 & 5 & 6 \\
\hline 1 & EP & 4.84 & 4.26 & 1 & & & & & \\
\hline 2 & Proactive Personality & 4.35 & 0.41 & $.807^{* *}$ & 1 & & & & \\
\hline 3 & Social Astuteness & 3.77 & 0.54 & $.497^{* *}$ & $.486^{* *}$ & 1 & & & \\
\hline 4 & Networking Ability & 3.23 & 0.74 & $.459^{* *}$ & $.399^{* *}$ & $.369^{* *}$ & 1 & & \\
\hline 5 & Self-Monitoring & 3.94 & 0.42 & $.500^{* *}$ & $.437^{* *}$ & $.378^{* *}$ & $.472^{* *}$ & 1 & \\
\hline 6 & Interpersonal Influence & 3.77 & 0.6 & $.571^{* *}$ & $.521^{* *}$ & $.454^{* *}$ & $.582^{* *}$ & $.700^{* *}$ & 1 \\
\hline
\end{tabular}

Source; (Field data, 2019)

\subsection{Testing For Hypotheses}

A multiple linear regression analysis was performed to calculate the coefficients of independent variables with employee performance. The combined prediction of all the variables accounted for approximately $69.6 \%$ of the total variation in employee performance $\left(R^{2}=.696\right.$, Adjusted $\left.R^{2}=.692\right)$. The ANOVA model showed that the joint prediction of all the independent variables as depicted in Table 3 
below was statistically significant $(F=192.360, \rho=.000$ ). Thus, the model was fit to predict employee performance using employee political skills.

The results presented in Table 3 below shows a positive and significant association between employee political skills (Proactive, Astuteness, networking, monitoring and Interpersonal) and employee performance as indicated by all the positive Betas $(\beta)$ and significance values of less than $0.05(\rho<.05)$. Therefore, the hypotheses supported

Results on proactive personality showed that proactive personality have a positive and significant effect on employee's performance in Kenyan Universities. Their performance was also found to be positively correlated with proactive personality. This finding was supported by Thompson, (2005), people with high proactive personality tend to be relatively unconstrained by situational forces and have a great effect on changing the environment. Additionally, they identify opportunities and show initiative to create meaningful changes in their environment. Those abilities have an influence on the variable of Employee performance, where employees identify with an organization, get involved in it, pursuing its goals and feel a strong bond towards it. Proactive people have been shown to engage in active surveying of their environment, maintaining vigilance, and enacting behaviours intended to bring about desired outcomes. Proactive people actively seek out new information and practices in order to improve their performance (Crant, 2000).

Social astuteness was found to have a positive and significant effect on employees' performance in Kenyan Universities. The results also showed that there is a strong positive significant correlation between social astuteness and employee's performance. The results were backed up by Balc1 (2000)successful socialization of an individual increases organizational commitment, harmony and success rate, joining of the individual to the organization to start a career and his/her progress in this career depends on the socialization program implemented by organizations and individual's success of this program. Not only socialization enables employees to have organizational commitment it also eases their adaptation to organizational values, rules, norms, methods and social relationship. Failure of an employee to socialize may lead the employee to leave the organization and this situation causes harm to both the employee and the organization. Also Eisenberger and others, (2001)supported the findings, with the satisfaction of social emotional needs like affiliation and emotional support a stronger identification with the organization improves their affective organizational commitment and thus improve performance which is felt by employees by getting involved in an exchange with the same actor again and again. 
Networking ability was found to have positive and significant influence on employees' performance in Kenyan Universities. These findings tallied with Baron \& Markman, (2000) who argued that individuals who are high in networking ability ensure they are well positioned in order to both create and take advantage of opportunities. Moreover, Blickle et al. (2009), in their longitudinal study proved that networking ability predicted career satisfaction, hierarchical position, and income. Only when employees are strong with networking ability, are they able to navigate the political environment at workplace thereby optimizing resources and power, can exercise influence, and are able to gain personal and company goals through organizational commitment.

Self-monitoring was found to have a positive and significant affecting employees' performance in Kenyan Universities. Rachlin (1999) supported the results, believes that individual with high selfmonitoring has higher employee performance within the organization in which they work for. Haland (2004) also backed up the result by suggesting that self-monitoring and locus of control have better organizational performance and, results showed that variables of self-monitoring and locus of control do not affect alone, but the combination of the two variables affect employee performance.

Interpersonal Influence correlated positively with casual employees' performance. McAllister (1995) supported the finding by interviewing 194 managers and professionals and his results demonstrate that managers with high affect-based trust in their colleagues are more inclined to look for opportunities to meet co-workers' work-related needs and to engage in productive intervention. This study builds path for future research on how trust among managers in organizations influence their behaviour and performance. Affective trust is closely related to the perception that a partner's actions are intrinsically motivated and characterized by feelings of security and perceived strength of the relationship. So the emotional ties that link individuals are accepted to be the basic antecedent for trust that leads to better performance in an Organization. 
Table 3. Multiple Regression

\begin{tabular}{|c|c|c|c|c|c|}
\hline & \multicolumn{2}{|c|}{$\begin{array}{l}\text { Unstandardized } \\
\text { Coefficients }\end{array}$} & \multicolumn{3}{|c|}{ Standardized Coefficients } \\
\hline & B & Std. Error & Beta & $\mathrm{T}$ & Sig. \\
\hline (Constant) & 0.462 & 0.125 & & 3.707 & 0.000 \\
\hline Proactive & 0.640 & 0.033 & 0.654 & 19.447 & 0.000 \\
\hline Astuteness & 0.067 & 0.028 & 0.077 & 2.388 & 0.017 \\
\hline Networking & 0.054 & 0.024 & 0.075 & 2.237 & 0.026 \\
\hline Monitoring & 0.072 & 0.032 & 0.086 & 2.243 & 0.025 \\
\hline Interpersonal & 0.079 & 0.037 & 0.092 & 2.136 & 0.033 \\
\hline \multicolumn{6}{|l|}{ Model Summary statistics } \\
\hline R Square & 0.696 & & & & \\
\hline Adjusted R Square & 0.692 & & & & \\
\hline Std. Error of the Estimate & 0.311 & & & & \\
\hline \multicolumn{6}{|l|}{ Model Fitness Statistics } \\
\hline ANOVA(F stat) & 192.360 & & & & \\
\hline ANOVA(F prob) & 0.000 & & & & \\
\hline
\end{tabular}

a Dependent Variable: performance

\section{Conclusion and Recommendation}

This section attempts to investigate a study of employee political skills on employee performance. Employee political skills positively impacts on employee performance. It can therefore be said that political skilled employees are an asset to the organization since politically skilled are more likely than less skilled employees to understand the social implications of resource expenditures, discern the present and potential value of social resources, and understand how they fit into others' functioning in the social environment for better performance. As well, they are effective in identifying opportunities within the work environment and persist until there is notable change in the organization.

The study also concludes that there is a significant statistical association between employees' personal attributes and employee performance in Kenyan universities. It is evident that where employees have competent skills, well trained, advanced career development, highly motivated, positive attitude among other attributes, the level of their production tends to be higher than organizations where employees do not possess these attributes. This implies that the employees' level of performance is significantly affected by personal attributes. Thus, there is need for organizations to improve personal attributes among employees, more especially on political skills in order to achieve the organization goals.

The study recommends that to improve on their productivity, Kenyan universities should consider encouraging and promoting all political skill. Since, political skills are a major predictor of employee 
performance. Employees who are politically skilled leverage their networks by ensuring that they are connected to influence others. The politically skilled also are more likely than less skilled employees to understand the social implications of resource expenditures, discern the present and potential value of social resources, and understand how they fit into others' functioning in the social environment. Failure also for an employee to socialize may lead the employee to leave the organization and this situation causes harm to both the employee and the organization As a result, it is essential for organizations to have employees with high political skills since they stand a better chance at taking advantage of opportunities that are beneficial to the organization.

Considering the foregoing, there is need also for organizations to focus on whether their employees are satisfied with their job because they are at a risk of losing dissatisfied employees that possess valuable set of skills. Also, it is of vital importance to assure employees that they will progress in their career within the organization. Kenyan university management should promote conducive work environments for their employees as this will enhance positive performance. Work environment as a sum of the interrelationship of various factors that exist among the employees and the employers need to be enhanced to moderate the constructs of political skills for positive performance.

\section{References}

Baker R., L. curseu, D. Vermeulen. (2007). Cognitive factors in entrepreneurial strategic decision making.Cognition, Brain, Behavior. Volume xl, Nol, (195-219)

Balci, Ali (2000). ÖrgütselGelişme: KuramveUygulama. Ankara: PegemaYayıncılık

Baron RA, Markman GD. (2000), Beyond social capital: How social skills can enhance entrepreneur's success, Academy of Management Executive, 14, 106-116

Becker T., (2004). Employee performance and motivation: A conceptual analysis and integrative model. Journal of Applied Psychology, 89, 991-1007,

Blickle, G., John, J., Ferris, G.R., Momm, T., Liu, Y., Haag, R., Meyer, G., Weber, K., \&Oerder, K. (2012a). Fit of political skill to the work context: A two-study investigation. Applied Psychology: An International Review, 61, 295-322.

Blickle, G., Kramer, J., Zettler, I., Momm, T., Summers, J.K., Munyon, T.P., \& Ferris, G.R. (2009), Job demands as a moderator of the political skill - job performance relationship, Career Development International, 14, 333-35.

Blickle, G., Oerder, K., \&Summers, J.K. (2010), The impact of political skill on career success of employees' representatives, Journal of Vocational Behavior, 77, 383-39.

Bolino, M. C., \&Turnley, W. H. (2003a). Counter-normative impression management, likeability, and performance ratings: The use of intimidation in an organizational setting. Journal of Organizational Behavior, 24: 237-25.

Boswell W., Boudceau J., Judye T., (2001).Effect of personality on executive career success in the United States and Europe.Journal of vocational behaviour. 58.N.1 
Bowling, N. A., Wagner, S. H., \&Libkuman, T. M Beehr, T. A.,. (2005). Adaptation levd theory, opponent process theory, and dispositions: An integrated approach to the stability of job satisfaction. Journal of Applied Psychology, 90, 1044-1053.

Byrne, Z. S. (2005). Fairness reduces the negative effects of organizational politics on turnover intentions, citizenship behaviour and job performance. Journal of Business and Psychology, 20(2), $175-20$.

Chen, Z. X., \& Francesco, A. M. (2002).The relationship between the three components of commitment and employee performance in China. Journal of Vocational Behavior, 62, 490-51.

Crant, J. M. (2000). Doing more harm than good: When is impression management likely to evoke a negative response? Journal of Applied Social Psychology, 26, 1454-1471

David P.A.. (2015) “Toward a new economics of science,” Research Policy23, 487-521.

DePasquale, J. P. \& Geller, E. S. (1999). Critical success factors for behaviour-based safety: A study of 20 industry-wide applications. Journal of Safety Research, Vol. 30, pp. 237-249.

Eby LT, Ng T, Sorensen KL and Feldman DC (2005), 'Predictors of objective and subjective career success: A meta-analysis', Personnel Psychology, 58(2), pp.367-409.

Eisenberger, R., J. Cummings, S. Armeli and P. Lynch (2001), “Perceived Organizational Support and Employee Diligence, Commitment, and Innovation", Journal of Applied Psychology,75, 51-59

Erdogan, B., \& Bauer, T. N. (2005).Enhancing career benefits of employee proactive personality: The role of fit with jobs and organizations. Personnel Psychology, 58, 859-891

Ferris, G. R. , Treadway, D. C. , Kolodinsky, R. W. , Hochwarter, W. A. , Kacmar, C. J. , Douglas, C. , \& Frink, D. D. (2015). Development and validation of the political skill inventory. Journal of Management, 31(1), 126-152.

Ferris, G. R. , Treadway, D. C. , Perrewé, P. L. , Brouer, R. L. , Douglas, C. , \& Lux, S. (2007). Political skill in organizations. Journal of Management, 33(3), 290-320

Ferris, G. R., Treadway, D. C., Kolodinsky, R. W., Hochwarter, W. A., Kacmar, C. J., (2005). Citizenship Behaviour: Examining Links Within and Across Western and Chinese Samples, In G. B. Graen (Ed.), Dealing With Diversity (pp. 219-264), Greenwich, CT: Information Age

Ferris, G.R. \& Treadway, D.C. (Eds.) (2012). Politics in organizations: Theory and research considerations. New York: Routledge/Taylor and Francis.

Ferris, G.R., Davidson, S.L. and Perrewé, P.L. (2005), Political Skill at Work: Impact on Work Effectiveness, Davies-Black Publishing, CPP Inc., Mountain View, CA.

Harrell-Cook, G. Ferris, G. R., \&Dulebohn, J. H. (2000). Organizational politics: The nature of the relationship between politics perceptions and political behaviour. In M. Lounsbury (Ed.). Research in the sociology of organizations, 17, 89-130

Harrell-Cook, G., G. R. Ferris and J. H. Dulebohn (1999).'Political behaviors as moderators of the perceptions of organizational politics work outcomes relationships', Journal of Organizational Behaviour, 20 (7), pp. 10931105.

Herman, P., \&Datta, D. K. (2014). Relationships between top management team characteristicsand international diversification: An empirical investigation. British Journal of Management,16(1), 6978.

Higgins, C. A., Judge, T. A., \& Ferris, G. R. (2003). Influence tactics and work outcomes: A metaanalysis. Journal of Organizational Behavior, 24, 89-106

Inkson K. (2004), Images of career: Nine key metaphors, Journal of Vocational Behavior, 65, 96-111. 
Jawahar, I.M., Meurs, J.A., Ferris.,G.R.and Hochwarter, W.A. (2018), "Self-efficacy and political skill as comparative predictors of task and contextual performance: a two-study constructive replication", Human Performance, Vol. 21 No. 3, pp. 138-157.

McAllister, C. P., Ellen, B. P., and Ferris, G. R. (2016). Social influence opportunity recognition, evaluation, and capitalization increased theoretical specification through political skill's dimensional dynamics. J. Manag. doi: 1.1177/0149206316633747

McAllister, D. J. (1995).Affect-and Cognition-Based Trust as Foundations for Interpersonal Cooperation in Organizations. The Academy of Management Journal 38:1, 24-59.

Oerder, K., Blickle, G., \&Summers, J.K. (2010), The impact of political skill on career success of employees' representatives, Journal of Vocational Behavior, 77, 383-390

Pasha, G. H. \&Khodadadi A, F. (2009). The relation between personal and job characteristics of employees with their organizational commitment in water and electricity organization of Ahvaz, New findings in psychology

Perrewé, P. L., Zellars, K. L., Ferris, G. R., Rossi, A. M., Kacmar, C. J., \& Ralston, D. A. (2004). Neutralizing job stressors: Political skill as an antidote to the dysfunctional consequences of role conflict stressors. Academy of Management Journal, 47: 141-152

Perrewé, P. L., Zellars, K. L., Rossi, A. M., Ferris, G. R., Kacmar, C. J., Liu, Y., et al., (2005).Political skill: An antidote in the role overload - strain relationship. Journal of Occupational Health Psychology, 10, 239-250

Perrewe', P.L. and Nelson, D. (2004), "Gender and career success: the facilitative role of political skill", Organizational Dynamics, Vol. 33, pp. 366-78

Rachlin, H. (1999). The science of self-control. Cambridge, MA: Harvard University Press

Seibert,S. E., Kraimer, M. L., \&Crant, J.M.(2001). What do proactive people do? A longitudinal model linking proactive personality and careersuccess. Personnel Psychology, 54, 845-874.

Semadar, A., Robins, G., \& Ferris, G. R. (2016). Comparing the validity of multiple social effectiveness constructs in the prediction of managerial job performance. Journal of Organizational Behavior, 27, 443-461

Sharifi, S., Salimi, G.H. \&Seyyedahmadi, A. (2010). The investigation of the relation of personal characteristics and organizational commitment in schoolmasters and teachers of elementary, guidance and high schools of Khansar, Scientific-Research Journal of New Solution in educational Management, Islamic Azad university, Marvdasht branch, 1 (4).

Sharma M and Hussain A 2013. Political Skills and Professional Commitment Among Employees of Public and Private Sector Organisations. Journal of the Indian Academy of Applied Psychology.

Silvester, J. (2008), The good, the bad, and the ugly: Politics and politicians at work, International Review of Industrial and Organizational Psychology, 23, 107-148

Sofijanova, E., \&Zabijakin-Chatleska, V. (2013). Employee involvement and organizationalperformance: evidence from the manufacturing sector in republic of Macedonia. TrakiaJournal of Sciences, 11(1), 31-36

Thompson, J.A. (2015), "Proactive personality and job performance: a social capital perspective", Journal of Applied Psychology, Vol. 90 No. 5, pp. 1011-1017.

Treadway DC, Breland JW, Adams GL, Duke AB, Williams LA. (2010). The interactive effects of political skill and future time perspective on career and community networking behavior, Social Networks, 32, 138-147 
Treadway, D. C., Ferris, G. R., Duke, A. B., Adams, G., \& Thatcher, J. B. (2007). The moderating role of subordinate political skill on supervisors' impressions of subordinate ingratiation and ratings of interpersonal facilitation. Journal of Applied Psychology, 92, 848-855

Treadway, D.C., Hochwarter, W.A., Kacmar, C.J., \& Ferris, G.R. (2013). Political will, political skill, and political behavior. Journal of Organizational Behavior, 26: 229-245.

Valle, M., \& Witt, L. A. (2001).The moderating effect of teamwork perceptions on the organizational politics-job Satisfaction relationship. Journal of Social Psychology, 141(3), 379-388. http://dx.doi.org/1.1080/00224540109600559

Vigoda-Gadot, E., \&Drory, A. (Eds.), (2006), Handbook of organizational politics, Northampton, MA: Edward Elgar Publishing.

Vigoda-Godat, E., Vinarski-Peretz, H., \& Ben-Zion, E. (2003). Politics and image in the organizational landscape: An empirical examination among public sector employees. Journal of Managerial Psychology, 18, 764-788.

Wagner, S. H., \&Libkuman, T. M Bowling, N. A., Beehr, T. A.,. (2005). Adaptation levd theory, opponent process theory, and dispositions: An integrated approach to the stability of job satisfaction. Journal of Applied Psychology, 90, 1044-1053.

Wei, L-Q., Liu, J., Chen, Y-Y., \& Wu, L-Z. (2010), Political skill, supervisor-subordinate guanxi and career prospects in Chinese firms, Journal of Management Studies, 47,437-54

Yin-Fah, B.C., Y.S. Foon, L. Chee-Leong and S. Osman, (2010).An exploratory study on turnover intention among private sector employees.int. J. Bus. Manager, 5: 57-64

Zaki, H.R. \&Muhammadi, N. (2003).The relation between locus of control and personal characteristics, Thought and behavior, 5 (18). 